\title{
Yaşlılarda Klinik Beslenme ve Sıvı Durumu: Kanıta Dayalı Uygulama Önerileri
}

\author{
Merve KELEŞ $^{1}$ iD Meryem Yavuz VAN GIERSBERGEN ${ }^{2}$ iD
}

\author{
${ }^{1}$ Ege Üniversitesi, Hemşirelik Fakültesi, Hemşirelik Bölümü, İzmir, Türkiye mervewcagla@ gmail.com \\ (Sorumlu Yazar/Corresponding Author)
}

${ }^{2}$ Ege Üniversitesi, Hemşirelik Fakültesi, Hemşirelik Bölümü, İzmir, Türkiye, meryemyavuz2010@ gmail.com

\begin{tabular}{|c|c|}
\hline Makale Bilgileri & ÖZ \\
\hline $\begin{array}{l}\text { Makale Geçmişi } \\
\text { Geliş: } 10.06 .2020 \\
\text { Kabul: 03.10.2020 } \\
\text { Yayın: 25.12.2020 } \\
\text { Anahtar Kelimeler: } \\
\text { Yaşlilarda hidrasyon, } \\
\text { Yaşlilarda klinik } \\
\text { beslenme, } \\
\text { Beslenme yöntemleri. }\end{array}$ & 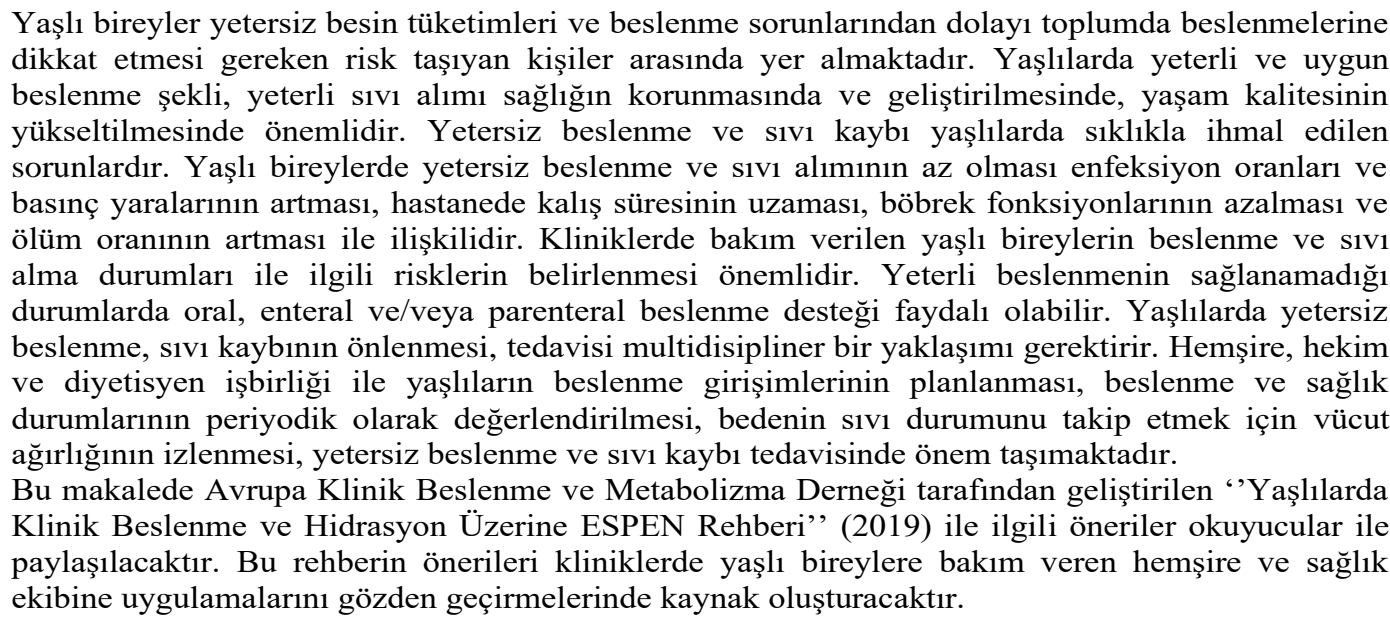 \\
\hline
\end{tabular}

\section{Clinical Nutritionand Hydration in Geriatrics: Evidence Based Practices} Recommendations

\begin{tabular}{|c|c|}
\hline ArticleInfo & ABSTRACT \\
\hline $\begin{array}{l}\text { Article History } \\
\text { Received: } 10.06 .2020 \\
\text { Accepted: } 03.10 .2020 \\
\text { Published: } 25.12 .2020 \\
\text { Keywords: } \\
\text { Hydration in } \\
\text { geriatrics, } \\
\text { On Cinical nutrition } \\
\text { in geriatrics, } \\
\text { Nutrition methods. }\end{array}$ & $\begin{array}{l}\text { Elderly people are among the people who should pay attention to their nutrition in the society due to their } \\
\text { inadequate food consumption and nutritional problems. Sufficient and appropriate nutrition in the elderly, } \\
\text { adequate fluid intake are important in maintaining and improving health and increasing the quality of life. } \\
\text { Malnutrition and dehydration are frequently neglected problems in the elderly. Malnutrition and low fluid } \\
\text { intake in elderly individuals are associated with increased infection rates and pressure sores, prolonged } \\
\text { hospital stay, decreased renal function, and increased mortality It is important to determine the risks related to } \\
\text { the nutritional and fluid intake of elderly people who receive care in clinics. In cases where adequate nutrition } \\
\text { cannot be provided, oral, enteral and / or parenteral nutritional support may be beneficial. Malnutrition, } \\
\text { prevention and treatment of dehydration in the elderly require a multidisciplinary approach. Planning } \\
\text { nutritional interventions of the elderly with the cooperation of nurses, doctors and dieticians, periodically } \\
\text { evaluating their nutrition and health status, monitoring body weight to follow the fluid status of the body, are } \\
\text { important in the treatment of malnutrition and dehydration. } \\
\text { In this article, recommendations regarding the "ESPEN Guide on Clinical Nutrition and Hydration in the } \\
\text { Elderly" (2019) developed by the European Society of Clinical Nutrition and Metabolism will be shared with } \\
\text { the readers. The recommendations of this guideline will serve as a resource for nurses and healthcare } \\
\text { professionals who care for elderly people in clinics to review their practices. }\end{array}$ \\
\hline
\end{tabular}

Atıf/Citation: Keleş, M. \&Yavuz Van Giersbergen, M. (2020). Yaşlılarda klinik beslenme ve sıvı durumu: Kanıta dayalı uygulama önerileri, Genel Să̆llk Bilimleri Dergisi, 2(3), 188-199. 


\section{GİRIŞ}

Hastalıkların ve sağlık sorunlarının büyük bir bölümü dengesiz ve yetersiz beslenmeden kaynaklanmaktadır (Ardahan ve Baz, 2016). Yetersiz beslenme, insan metabolizmasında değişikliğe neden olan, vücudun işlevini tehlikeye atan ve vücut kütlesi kaybına neden olan alım ve gereksinimler arasındaki dengesizlik olarak tanımlanmıştır (Martin ve ark., 2015). Yetersiz beslenme; enerji, protein ve diğer besin maddelerinin eksikliğinin veya fazlalığının ya da dengesizliğinin doku /beden formu (vücudun şekli, büyüklüğü, bileşimi) ve işleviyle klinik sonuç üzerinde ölçülebilen olumsuz etkilere neden olduğu bir beslenme durumudur (Lochs ve ark., 2006).

Yeterli ve dengeli beslenme daha kaliteli bir yaşamın sürdürülmesini sağlayarak bireylerin sağlığının korunmasında ve geliştirilmesinde önemli rol oynar (Cindemir, 2008). Yaşlanmaya bağlı olarak ortaya çıkan hastalıkların önlenmesinde ve tedavi edilmesinde beslenme önemli sağlı ve refah düzenleyicisidir (Aksoydan, 2008; Volkert, 2019). Türkiye'de 65 yaş ve üzeri yaşlı bireylerin büyük çoğunluğu, yetersiz ve uygun olmayan beslenme şeklinin sebep olduğu hastalıkların etkisindedir. $\mathrm{Bu}$ yaş gruplarında görülen obezite, diyabet, kalp-damar hastalıkları, osteoporoz, felç, iskelet ve kas sistemi hastalıklarında dengesiz beslenme tarzı risk etkenidir (TR Beslenme Raporu, 2015). Beslenmenin daha iyi olması, yaşlılarda fiziksel performansı iyileştirir ve yorgunluğu azaltır (Cemali ve ark., 2018).

Yaşlı bireylerde beslenme durumu pek çok etkenden etkilenmektedir (Vural ve ark., 2018). Bu etkenler, yaşlanma sürecinde vücutta oluşan değişiklikler, kronik hastalıklar, kullanılan ilaçlar, fiziksel, psikolojik, sosyal ve ekonomik durumdur (Aksoydan, 2008). Beslenme durumunun değerlendirilmesi, hastalık ve ölüm riski yüksek olan bireylerin tanımlanması ve yönetilmesi açısından önemlidir (Rubino ve ark., 2020). Beslenme durumunun uygun değerlendirilmesi; yetersiz beslenmeyi erken tespit etmede, riskleri ve olası beslenme eksikliklerinin nedenlerini tespit etmede, hastaların beslenme durumunu iyileştirmek için eylem planları hazırlamada ve beslenme girişimleri üzerindeki etkinliği değerlendirmede önemli bir yer almaktadır (Martin ve ark., 2015).

\section{Yaşlılarda Beslenme Durumunun Değerlendirilmesi}

Yaşlı bireylerde beslenme durumunu değerlendirmenin pek çok yolu bulunur:

\section{- Malnütrisyon Riski Taramalart}

Malnütrisyon (Beslenme yetersizliği) riski taraması için birkaç test mevcuttur. "Mini Beslenme Değerlendirilmesi'" bu testlerden biridir ve çeşitli sorularla muhtemel malnütrisyon durumu ortaya koyulur. Mini Beslenme Değerlendirmesi, yaşl1larda malnütrisyonu tespit etmek için güvenilir bir tarama testi olarak geliştirilmiştir. Herhangi bir laboratuvar verisi olmadan, hastaların beslenme durumu sorular ve antropometrik ölçümlerle kolayca tahmin edilebilir. "Beslenme Sağlığını Belirle” isimli beslenme kontrol listesi de başka bir malnütrisyon riski taramasıdır. "Beslenme Sağlığını Belirle'” testi sonucunda orta veya yüksek riskli yaşlı hastaların, değerlendirme için diyetisyene gönderilmesi gerekmektedir. Böylece malnütrisyon riski taşıyan yaşlılar belirlenmiş olur (Mercanlıgil, 2008; Saka, 2010).

\section{- $\quad$ Antropometrik ölçümler}

Yaşl1ların beslenme durumunun saptanmasında protein ve yağ deposunun bir göstergesi olduğundan en önemli yöntemlerden biri antropometridir (Tulukçu, 2019). Boy uzunluğu ve vücut ağırlığı da yaşla beraber azaldığı için boy uzunluğunun, vücut ağırlığının doğru bir şekilde belirlenmesi, bazal metabolizma hızı, enerji gereksinimi ve harcamasının belirlenmesinde önemlidir (Pekcan ve Saruhan, 2001).

\section{- Laboratuvar bulgulart}

Beslenme durumu değerlendirilirken laboratuvarda ölçülen serumdaki protein seviyeleri de diğer parametrelerle beraber kullanılmaktadır. Bu nedenle albümin, transferrin ve prealbümin kullanılır (Yentür, 2011). Biyokimyasal testlerle besin öğelerinin kandaki ve idrardaki seviyeleri saptanarak yaşlı bireylerde 
beslenme durumu ile ilişkili nesnel değerlendirme yapılabilir. Yaşla birlikte serum albumin seviyesi azalır. Serumdaki albümin seviyesi 20 ile 40 yaşları arasında ortalama 47,5 g/L iken, 60 ile 74 yaşları arasında 41.8 g/L'ye düşer. Biyokimyasal ve hematolojik testler kan proteinleri, kan yağları, kanda ve idrarda vitamin, mineral seviyeleri, hemoglobin, hematokrit, demir, folik asit ve anemi açısından beslenme durumunu belirlemektedir (Özgüneş, 2013; Pekcan, 2008).

\section{Beslenme Yöntemleri}

Beslenme destek tedavisinde öncelikle normal yoldan beslenme sağlanmalı ve beslenme eksiklikleri giderilmelidir. Bunun için beslenme desteği, ara ögünlerin kuvvetlendirilmesi, yemek yenilme ortamının şartlarının düzenlenmesi gibi birkaç etken bununla ilişkilendirilebilir. Normal yoldan alınan gıdalar yetersizse ağızdan verilen hazır zenginleştirilmiş beslenme destek ürünlerinin yararı bilimsel çalışmalarla desteklenmiştir (Arığul, 2013).

Tarama ve değerlendirmeler neticesinde malnütrisyon ya da malnütrisyon riski saptanmış hastalara beslenme destek tedavisi planlanması gerekmektedir. Beslenme destek tedavisinde yaşlı bireylerin oral alımı varsa diyetisyenle işbirliği halinde oral alım desteklenir ve oral destek ürünleri verilir (Ardahan ve Baz, 2016). Oral desteklenme yetersizse sırasıyla enteral ve parenteral karışımı ya da parenteral beslenme yolları kullanılabilir (Tek ve Yeşildemir, 2018). Enteral beslenme, ağızdan başlayıp jejunuma kadar olan bölgelere; doğrudan, bir tüple, perkütan girişimlerle ya da cerrahi teknikle yapılabilir (Gülseven ve Gürkan, 2013). ‘ "Total parenteral beslenme (hiperalimentasyon), besinlerin gastrointestinal yoldan alınmasının mümkün olmadığı ya da alınmaması gerektiği durumlarda hastaların gereksinimlerini karşılamak amacıyla kullanılan bir yöntemdir" ' (Üstündağ, 2001, s.41). Yaşl1larda enteral beslenme ile ilgili ESPEN (Avrupa Parenteral ve Enteral Beslenme Derneği) kılavuzları, enerji ve besin alımını arttırmak ve beslenme durumunu iyileştirmek veya sürdürmek için yetersiz beslenen ya da yetersiz beslenme riski saptanmış hasta bireylerde oral besin takviyeleri kullanılmasını önermektedir (Streicher ve ark., 2017). Oral besin takviyeleri nazogastrik tüple besleme yoluyla birlikte nazoenteral veya perkütan tüple beslemeyi de içerir (Lochs ve ark., 2006).

Yaşlı bireylerin birçoğunda, bedensel hastalıklar sırasında geçici kafa karışıklığı riskini artırabilecek bilişsel eksiklikler ya da başka zihinsel bozukluklar bulunur. Böyle durumlarda, nazogastrik tüplerin hasta tarafından çıkarılması olasıdır. Ayrıca, gastrointestinal sistemde yaşa bağlı değişiklikler, özellikle kritik hastalıklarda ve besin emiliminin etkinliği açısından göz ardı edilmemelidir. Bu nedenle, oral / enteral ve parenteral beslenme, birbirini dışlamaz ve birbirini tamamlar (Sobotka ve ark., 2009).

Yaşlıların yeterli ve uygun beslenmesi, yaşam standartlarının artmasında, çeşitli hastalıkların önlenmesinde etkili olduğundan, yaşlı bireylerin beslenme durumları belirli aralıklarla değerlendirilmesi gerekmektedir (Yabancı ve ark., 2012). Yaşlilarda beslenme üzerine geliştirilmiş rehberler bulunmaktadır:

1. Avrupa Klinik Beslenme ve Metabolizma Derneği (ESPEN) tarafından 2019 yılında geliştirilen "Yaşlılarda Klinik Beslenme ve Hidrasyon Üzerine ESPEN Rehberi"

2. Amerikan Parenteral ve Enteral Beslenme Derneği (ASPEN), Beslenme ve Diyetetik Akademisi'nin Amerikan Beslenme ve Metabolizma Tanımları Birliği Avrupa Topluluğu tarafından 2019 yılında geliştirilen "'ASPEN ve ESPEN Rehberi'” Rehberi"

3. İngiliz Geriatri Derneği tarafından 2009 yılında geliştirilen "Beslenme Önerileri Üzerine Nice

4. Hartford Geriatri Hemşirelik Enstitüsü tarafından 2008 yılında geliştirilen "Yaşlılarda Beslenme Üzerine Klinik Uygulamada Beslenme Rehberi”

\section{Yaşlılarda Sıvı Kaybı}

Yaşlı bireylerde sıvı tüketimi çok önemli bir konudur fakat sıklıkla göz ardı edilir (Özgüneş, 2013). Kötü beslenmenin yanı sıra, yaşlılar, ciddi sağlık sonuçları olan çeşitli nedenlerden dolayı artan sıvı kaybı 
riski de altındadır (Volkert ve ark., 2019). Yaşıı bireylerde fizyolojik ve bilişsel değişikliklerden dolayı sıvı kaybı gelişme riski genç bireylere göre daha yüksektir (Mentes 2006; Mistura, 2016). Yaşl1larda sıv1 kayb1 için kesin bir tanım bulunmamaktadır. Sıvı kaybı, vücut ağırlığının \%3'ünden daha hızlı kilo kaybı olarak tanımlanırken biyokimyasal açıdan sıvı kaybı, çoğunlukla serum sodyumunun $148 \mathrm{mmol} /$ L'ye eşit ya da daha büyük olduğu ve / veya kan üre nitrojen (BUN) oranının 25 'ten büyük ya da eşit olduğu durum olarak tanımlanır (Hodgkinson ve ark., 2003). Sıvı kaybı 65 yaş üzeri bireylerin hastaneye yatırılmasının en önemli on nedeninden biridir (Bratlund ve ark., 2010). Sıvı kaybı yaşlıların \%20 ile \%30'unu etkiler. Genç bireylere göre daha büyük bir negatif sonuç olduğundan mortalite, morbidite ve sakatlığı arttırır. Sıvı kaybı genellikle yaşlılarda su tüketilmemesinden kaynaklanır veya aşırı su kaybı da bir neden olabilir. Yaşlılarda sıvı kaybının klinik değerlendirmesinde farklı bulgular ortaya çıkmaktadır, ancak her zaman teşhis tanınamayabilir. Sıvı kaybı tedavisinde; kayıp, sağlı̆̆ı olumsuz yönde etkilemeden ve çeşitli bozukluklara yol açmadan önce önleme ve erken tanıya odaklanılır (Miller, 2015).

Yaşlılarda yetersiz sıvı alımı sıvı kaybıyla sonuçlanmaktadır (Güleç, 2013). Sıvı kaybının tespit edilmesinde yardımcı olabilecek bazı belirtiler bulunur. Hücre hacmindeki azalma, kafa karışıklı̆̆ı, baş ağrısı, uyuşukluk, baş dönmesi, kuru buruşuk cilt ve / veya azalan cilt turgoru gibi belirtiler olabilir. Sıvı atılımındaki azalma, dudaklarda kuruluk, tükürük salgısında azalma, göz kuruluğu, koltukaltının ya da avuç içinin kuru olması, kan volümünün düşük olması, kapilller dolumun yavaş olması, düşük kan basınc1, zayıf nabız, hızlı kalp atışı ya da ortostatik hipotansiyon ile sıvı kaybı tanımlanabilir (Hooper ve ark., 2014).

Avrupa Klinik Beslenme ve Metabolizma Derneği tarafından 2019 yılında geliştirilen "Yaşlılarda Klinik Beslenme ve Hidrasyon Üzerine ESPEN Rehberi', ile yaşlılarda yetersiz beslenme, sıvı kaybını önlemek ya da tedavi etmek için klinik beslenme ve sıvı durumuna ilişkin kanıta dayalı öneriler sunulması amaçlanmıştır. Bu makalede, bu rehberin önerileri incelenecektir. Rehberdeki kanıt düzeyleri Tablo 1'de verilmiştir.

Tablo 1.Yaşlılarda Yetersiz Beslenme ve Sıvı Durumu: ESPEN Rehberinde Sunulan Kanıt Düzeyleri

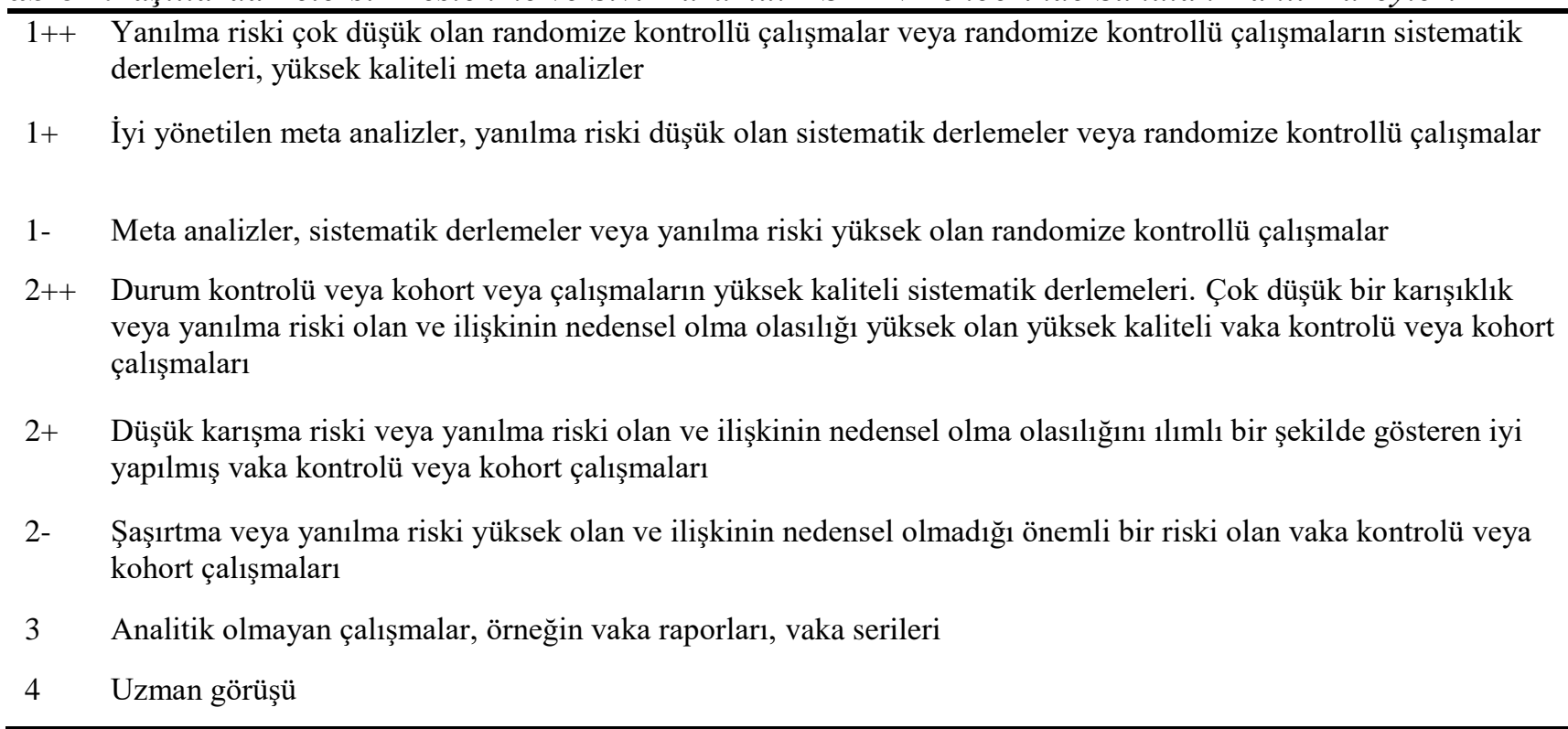

Bu rehber, diğer ESPEN rehberleri ve ortak karar bildirilerine uygun standart çalışma süreçlerine göre geliştirilmiştir. PICO (Hasta, Müdahale, Karşılaştırma ve Sonuç) formatında 33 klinik soruyu temel alan sistematik derleme ve en önemli çalışmalar için sistematik bir literatür taraması yapılmıştır. Mevcut kanıtlar SIGN derecelendirme sistemine göre derecelendirilmiştir. Bir ortak karar sürecinde 82 tane öneri geliştirilmiş ve kabul edilmiştir. Belirlenen kanıt seviyelerine göre, öneri derecelerine karar verilmiştir. Öneri dereceleri Tablo 2'de gösterilmiştir. 
Tablo 2.Yaşlılarda Yetersiz Beslenme ve Sıvı Durumu: ESPEN Rehberinde Sunulan Öneri Dereceleri

\begin{tabular}{|c|c|}
\hline $\bar{A}$ & $\begin{array}{l}\text { Hedef gruba doğrudan uygulanabilir en az bir meta-analiz, sistematik inceleme veya randomize kontrollü } \\
\text { çalışmalar } 1++ \text { olarak derecelendirilmiş veya temel olarak } 1+\text { olarak değerlendirilen, hedef kitleye doğrudan } \\
\text { uygulanabilir ve sonuçların genel tutarlılığın gösteren bir kantlar bütünüdür. }\end{array}$ \\
\hline B & $\begin{array}{l}\text { Yeterli kanıtlar içeren hedef kitleye doğrudan uygulanabilir çalışmalar } 2++ \text { olarak derecelendirilmiştir veya } \\
\text { yeterli kanıtlar içeren hedef kitleye doğrudan uygulanabilir ve sonuçların genel tutarlıllğını gösteren çalış̧malar } \\
2+\text { olarak derecelendirilmiștir veya tahmin olarak yürütülen çalışmalar } 1++ \text { ya da } 1+\text { olarak derecelendirilmistir. }\end{array}$ \\
\hline 0 & Kanit seviyeleri 3 veya 4 \\
\hline GPP & $\begin{array}{l}\text { Tahmin olarak yürütülen çalışmalar } 2++ \text { ya da } 2+\text { olarak derecelendirildi. } \\
\text { İvi uvoulama noktalar/uzman görüsleri. Rehber gelistirme orubunun klinik denevimde önerilen en jvi uvoulama }\end{array}$ \\
\hline
\end{tabular}

Tüm ESPEN üyeleri önerilere katılmaya veya yorumda bulunmaya davet edilmiştir. Bu vesileyle ilk kılavuz taslağı katılımcılara da sunulmuştur. Altmış beş tavsiye $>\% 90$ bir anlaşmaya ulaşılmış, 17 tavsiye > \% 75-90 arasında bir anlaşmaya ulaşılmış ve yalnızca bir öneri \% 75 olmuştur. \%90'dan yüksek bir anlaşmaya sahip olan bu öneriler, bu da güçlü bir fikir birliği anlamına gelir (Tablo 3). Öneriler ise Tablo 4'te gösterilmiştir.

Tablo 3. Yaşlılarda Yetersiz Beslenme ve Sıvı Durumu: ESPEN Rehberinde Sunulan Uzlaşma Gücünün Siniflandirılması

\begin{tabular}{ll}
\hline Güçlü fikir birliği & Katılımcıların $>\%$ 90'ının sözleşmesi \\
Fikir birliği & Katılımcıların \% 75 - 90'ı arası anlaşma \\
Çoğunluk anlaşması & Katılımcıların $>\% 50-75^{\prime}$ arasında anlaşma \\
Fikir birliği yok & Katılımcıların $<\% 50$ 'sinin anlaşıllması \\
\hline
\end{tabular}

Tablo 4. Yaşlılarda Yetersiz Beslenme ve Sivı Durumu: ESPEN Rehberinde Sunulan Öneriler

\begin{tabular}{|c|c|}
\hline Madde & Öneri \\
\hline $1-$ & $\begin{array}{l}\text { Yaşlı bireylerde enerji alımı için yol gösterici değer, kilosu başına günde } 30 \text { kcal'dir. } \\
\text { Bu değer, beslenme durumu, fiziksel aktivite seviyesi, hastalık durumu ve tolerans } \\
\text { açısından bireysel olarak ayarlanmalıdır. }\end{array}$ \\
\hline $2-$ & $\begin{array}{l}\text { Yaşlı bireylerde protein alımı, } \mathrm{kg} \text { başına günde en az } 1 \text { gr protein olmalıdır. Miktar, } \\
\text { beslenme durumu, fiziksel aktivite seviyesi, hastalık durumu ve tolerans açısından } \\
\text { bireysel olarak ayarlanmalıdır. }\end{array}$ \\
\hline $3-$ & Enteral beslenme için lif içeren ürünler kullanılmalıdır. \\
\hline 4- & $\begin{array}{l}\text { Özel bir eksiklik olmaması koşuluyla mikro besinler sağlıklı yaşlılar için önerilere } \\
\text { göre verilmelidir. }\end{array}$ \\
\hline 5- & $\begin{array}{l}\text { Özel bir tanıdan bağımsız olan ve ayrıca fazla kilolu ve şişman kişiler de dâhil olmak } \\
\text { üzere tüm yaşlı bireyler, yetersiz beslenme durumlarını riskini tespit etmek için } \\
\text { doğrulanmış bir araçla düzenli olarak taranmalıdır. }\end{array}$ \\
\hline
\end{tabular}

6- $\quad$ Bir malnütrisyon taraması sistematik değerlendirme, bireysel girişimlerin izlenmesi ve yapılacakların buna göre ayarlanması ile takip edilmelidir.

7- Kurumsal ortamlarda, beslenme ve sıvı durumu için standart bakım protokolü oluşturulması sorumlulukları daha iyi düzenler.

8- $\quad$ Yeterli besin alımını sağlamak, beslenme durumunu sürdürmek veya iyileştirmek yaşlı bireylerin klinik seyri ve yaşam kalitesini iyileştirmek için beslenme ve sıvı alımı bireysel ve kapsamlı olmalıdır.

9- $\quad$ Yaşlı bireyler için beslenme girişimleri, yeterli diyet alımını desteklemek, vücut ağırlığını korumak veya artırmak, fonksiyonel ve klinik sonuçları iyileştirmek için multimodal ve multidisipliner bir takım çalışmasının parçası olmalıdır.

10- Kötü beslenme ve sıvı kaybının olası nedenleri mümkün olduğunca belirlenmeli ve ortadan kaldırılmalıdır.

11- Diyet alımını sınırlayabilecek diyet kısıtlamaları potansiyel olarak zararlıdır ve bunlardan kaçınılmalıdır.

12- Yetersiz beslenme veya yetersiz beslenme riski olan ve kurumlarda (A) ve evde (GPP) yeme bağımlılığı olan yaşlılara, önerilen diyet alımını desteklemek için yemek zamanı yardımı önerilir.

13- Kurumsal ortamlarda, yetersiz beslenme veya yetersiz beslenme riski olan yaşlıların yiyecek alımı, yeterli diyet alımını desteklemek ve yaşam kalitesini korumak için ev benzeri, hoş bir yemek ortamı ile desteklenebilir.

Kanit düzeyleri

B - Güçlü fikir birliği

(\%97 anlaşma)

B - Güçlü fikir birliği

(\%100 anlaşma)

B - Güçlü fikir birliği (\%91 anlaşma)

GPP - Güçlü fikir birliği

(\% 91 anlaşma)

GPP - Güçlü fikir birliği

(\% 100 anlaşma)

GPP - Güçlü fikir birliği (\% 100 anlaşma)

GPP - güçlü fikir birliği (\% 100 anlaşma)

A - Güçlü fikir birliği

(\%100 anlaşma)

B - Güçlü fikir birliği (\%100 anlaşma)

GPP - Güçlü fikir birliği (\%95 anlaşma)

GPP - güçlü fikir birliği (\% 91 anlaşma)

A / GPP - Güçlü fikir birliği (\% 100 anlaşma)

A - Güçlü fikir birliği (\%100 anlaşma) 
14- Beslenme alımını teşvik etmek ve yaşam kalitesini arttırmak için beslenme bozukluğu olan veya yetersiz beslenme riski taşıyan yaşlı bireylerin yemek zamanlarını başkalarıyla paylaşmaları teşvik edilmelidir.

15- Evde tekerlekli sandalyede yaşayan yetersiz beslenme ve yetersiz beslenme riski olan yaşlıların yemekleri enerji verici bakımından yoğun olmalı ve/veya yeterli miktarda besin almayı desteklemek için ek yemekler dâhil edilmelidir.

16- Yetersiz beslenme veya yetersiz beslenme riski taşıyan yaşlı bireylere, beslenme sorunları hakkında farkındalığı ve bilgiyi geliştirmek ve böylece yeterli beslenme alımını teşvik etmek için kapsamlı bir girişimin bir parçası olarak beslenme bilgisi ve eğitimi önerilmelidir.

17- Sağlık bakım profesyonellerinin yanı sıra hasta bakıcılara ve yetersiz beslenme veya yetersiz beslenme riski taşıyan yaşlı bireylere yönelik farkındalık sağlamak için beslenme eğitimi ve beslenme problemleri hakkında temel bilgiler sunulmalı ve böylece yeterli besin alımı teşvik edilmiș olur.

18- Beslenme bozukluğu olan veya yetersiz beslenme riski altında olan yaşlılara ve/veya bakıcılarına, yeterli beslenme alımını desteklemek ve beslenme durumunu iyileştirmek veya sürdürmek için kişiselleştirilmiş danışmanlık önerileri önerilebilir.

19- Bireyselleştirilmiş beslenme danışmanlığı, yaşlı bireylere ve/veya bakıcılarına deneyimli bir diyetisyen tarafindan sunulmalı, grup oturumları, telefon rehberleri ve yazılı önerilerle birleştirilecek birkaç (en az 2) bireysel seanstan oluşmalı ve daha uzun bir süre boyunca sürdürülmelidir.

20- Yetersiz beslenme veya yetersiz beslenme riski olan yaşlı bireylere yeterli diyet alımını desteklemek için takviye edilmiş yiyecekler verilmelidir

21- Beslenme alımını kolaylaştırmak için, yetersiz beslenme veya yetersiz beslenme riski taşıyan yaşlı bireylere ek atıştırmalıklar ve/veya elle yenen yemekler sunulmalıdır.

22- Yetersiz beslenme veya yetersiz beslenme riski ve orofarengeal disfaji belirtileri ve/veya çiğneme problemi olan yaşlılara, yeterli besin alımını desteklemek için dengeleyici bir strateji olarak doku değişimli zenginleştirilmiş gıdalar önerilebilir.

23- Beslenme danışmanlığı ve besin takviyesi diyet alımını artırmak ve beslenme hedeflerine ulaşmak için yeterli olmadığında, yetersiz beslenmeye sahip olan veya kronik koşullarla yetersiz beslenmeye maruz kalma riski olan yaşlılara oral besin takviyeleri sunulabilir.

24- Yetersiz beslenme veya yetersiz beslenme riski olan yaşlılara, besin alımını ve vücut ağırlığını geliştirmek, komplikasyon ve hastaneye yeniden yatış riskini azaltmak için oral besin takviyeleri verilebilir.

25- Hastaneden taburcu edildikten sonra, diyet alımını ve vücut ağırlığını iyileştirmek ve fonksiyonel düşüş riskini azaltmak için yetersiz beslenme veya yetersiz beslenme riski olan yaşlilara oral besin takviyeleri sunulabilir.

26- $\quad$ Yetersiz beslenme veya yetersiz beslenme riski olan yaşlı bireylere 30 gr veya daha fazla protein/gün içeren en az $400 \mathrm{kcal} /$ gün oral besin takviyeleri verilebilir.

27- Yetersiz beslenme veya yetersiz beslenme riski olan yaşlı bireylere oral besin takviyeleri en az bir kez kullanıldığında oral besin takviyelerinin etkinliği ve faydası ayda bir kez değerlendirilebilir.

28- Yetersiz beslenme veya yetersiz beslenme riski olan yaşlı bir bireye oral beslenme takviyeleri önerildiğinde, düzenli olarak değerlendirilmelidir. Tüketim şekli, tat duyusu, özellikleri ve süresi hastanın zevkine ve yeme kapasitesine uyarlanmalıdır.

29- Beslenmeyi karşılamak için yeterli oral alımın sağlanmasına yönelik girişimlere rağmen, oral alımın üç günden uzun bir süre için sağlanamaması veya bir haftadan daha uzun bir süre boyunca enerji ihtiyacının yarısının altında olan yaşlılara beslenme gereksinimleri ve beslenme durumunu korumak veya geliştirmek için uygun bir prognoz sağlanmalıdır.

30- Enteral beslenmenin yararları ve potansiyel riskleri ayrı ayrı değerlendirilmeli ve düzenli olarak ve klinik durum değiştiğinde yeniden değerlendirilmelidir.

31- Hastalığın son aşamasında düşük beslenme alımına sahip yaşlılara enteral beslenme yerine rahat beslenmeleri önerilebilir.

32- $\quad$ Enteral beslenme istendiğinde gecikmeden başlatılmalıdır.

33-- Dört haftadan daha az bir süre için enteral beslenmeye ihtiyaç duyan yaşlı hastalara nazogastrik tüp kullanılmalıdır.

34- Dört haftadan daha uzun süre boyunca enteral beslenmeye ihtiyaç duyan veya nazogastrik tüp istemeyen veya tolere edemeyen yaşlı hastalara perkütangastrostomi / PEG takılmalıdır.
GPP - Güçlü fikir birliği (\% 100 anlaşma)

B - Güçlü fikir birliği (\%97 anlaşma)

B - Güçlü fikir birliği (\%94 anlaşma)

B - Güçlü fikir birliği (\%95 anlaşma)

B - Güçlü fikir birliği (\%100 anlaşma)

GPP -Güçlü fikir birliği (\% 97 anlaşma)

B - Güçlü fikir birliği (\%100 anlaşma)

GPP - Güçlü fikir birliği (\% 100 anlaşma)

GPP - Güçlü fikir birliği (\% 100 anlaşma)

GPP - Güçlü fikir birliği (\% 100 anlaşma)

A - Güçlü fikir birliği (\%100 anlaşma)

A - Güçlü fikir birliği (\%100 anlaşma)

A - Güçlü fikir birliği (\%97 anlaşma)

GPP - Güçlü fikir birliği (\% 100 anlaşma)

GPP - Güçlü fikir birliği (\% 100 anlaşma)

GPP - Güçlü fikir birliği (\% 100 anlaşma)

GPP - Güçlü fikir birliği (\% 100 anlaşma)

GPP - Görüş birliği (\%88 anlaşma)

GPP - Güçlü fikir birliği (\% 96 anlaşma)

GPP - Güçlü fikir birliği (\% 100 anlaşma)

GPP - Güçlü fikir birliği (\% 96 anlaşma) 
35- Tüple beslenen yaşlı hastalar, oral alımı mümkün olduğu kadar güvenli bir şekilde sürdürmeleri için teşvik edilmelidir.

36- Beslenme gereksinimlerini karşılamak için, oral ve enteral alımın üç günden fazla olmaması veya bir haftadan daha uzun bir süre boyunca enerji gereksinimlerinin yarısının altında olması bekleniyorsa, uygun prognozlu (beklenen fayda) yaşlılara beslenme durumunu korumak veya geliştirmek için parenteral beslenme önerilebilir.

37- Enteral beslenme, parenteral beslenme ve hidrasyon, temel bakımdan ziyade tıbbi tedaviler olarak kabul edilmeli ve bu nedenle yalnızca hastanın durumunu ve yaşam kalitesini iyileştirme veya sürdürme konusunda gerçekçi bir şans varsa kullanılmalıdır.

38- Yaşlı hastalar enteral beslenme veya parenteral beslenme veya hidrasyonu mümkün kılmak için farmakolojik sedasyon veya fiziksel kısıtlamalar almamalıdır.

39- Beslenme bozukluğu olan yaşlı hastalarda enteral beslenmeye ve parenteral beslenmeye erken başlanmalıdır; Yeniden besleme sendromundan (refeedingsyndrome) kaçınmak için ilk üç gün içinde kademeli olarak arttırılmalıdır.

40- Kötü beslenen yaşlilarda enteral beslenme ve parenteral beslenme tedavisinin ilk üç gününde, hafif eksiklik durumunda bile desteklenecek olan kan seviyelerinde fosfat, magnezyum, potasyum ve tiamin seviyelerine özellikle dikkat edilmelidir.

41- Beslenme girişimlerine ek olarak, yetersiz beslenme veya yetersiz beslenme riski taşıyan yaşlı kişilerin fiziksel olarak aktif olmaları ve kas kütlesini ve fonksiyonunu korumak veya geliştirmek için egzersiz yapmaları teşvik edilmelidir.

42- $\quad$ Egzersiz girişimleri sırasında, vücut ağırlığını korumak ve kas kütlesini korumak veya geliştirmek için yetersiz beslenme veya yetersiz beslenme riski olan yaşlı kişilere yeterli miktarda enerji ve protein sağlanmalıdır.

43- Kalça kırı̆̆ı olan yaşlı hastalara, gıda alımını artırmak ve komplikasyon riskini azaltmak için ameliyat sonrası oral beslenme takviyeleri uygulanabilir.

44- Kalça kırığı olan yaşlı hastalara, başka nedenlerle enteral beslenme için bir endikasyon olmadıkça, birdenbire tüple beslenme önerilmez

45- Kalça kırı̆̆ı olan yaşlı hastalarda, beslenme alımını iyileştirmek ve komplikasyon riskini azaltmak için ameliyat sonrası oral besin takviyeleri ameliyat öncesi parenteral beslenme ile kombine edilebilir.

46- Yaşı hastalarda kalça kırığı ve ortopedik cerrahi sonrası beslenme girişimleri, yeterli diyet alımını sağlamak, klinik sonuçları iyileştirmek ve yaşam kalitesini korumak için bireysel olarak uyarlanmış, çok boyutlu ve çok disiplinli bir ekip müdahalesinin bir parçası olmalıdır.

47- Acil ameliyat için hastaneye yatırılan tüm yaşlı hastalara, deliryumu önlemek için sıvı desteği ve beslenme yönetimini içeren çok bileşenli farmakolojik olmayan bir girişimde bulunulmalıdır.

48- Kliniğe kabul edilen ve orta ile yüksek deliryum riski taşıyan tüm yaşlı hastalar, deliryumu önlemek için sıvı desteği ve beslenme yönetimini içeren çok bileşenli farmakolojik olmayan bir müdahale almalıdır.

49- Mevcut deliryumu olan hastanede yatan yaşlı hastalar, deliryumun potansiyel nedenleri veya sonuçları olarak sıvı kaybı ve yetersiz beslenme açısından taranmalıdır Depresif yaşlı hastalar yetersiz beslenme açısından taranmalıdır.

$51-$
Depresyonu olan yaşlı hastalara, yetersiz beslenme veya yetersiz beslenme riski yoksa rutin olarak girişimler yapılmaz.

Yaşlı hastalarda basınç yarası riskini önlemek için beslenme ile ilgili destekler yapılmalıdır.

\section{beslenme girişimleri önerilmelidir.}

Fazla kilolu yaşlı kişilerde kas kütlesi kaybını ve buna eşlik eden fonksiyonel düşüşü önlemek için zayıflama diyetlerinden kaçınılmalıdır.

Kiloya bağlı sağlık problemleri olan şişman yaşlı kişilerde, kilo azaltıcı diyetlerin yarar ve riskleri sadece dikkatli ve bireysel tartıldıktan sonra dikkate alınmalıdır.

Aşırı kilolu kişilerde kilo kaybı göz önünde bulundurulursa, yavaş kilo vermeyi sağlamak ve kas kütlesini korumak için enerji kısıtlaması sadece makul düzeyde olmalıdır.

Aşırı kilolu yaşlı bireylerde kilo kaybı düşünülürse, kas kütlesini korumak için mümkün olduğunca diyet girişimleri fiziksel egzersiz ile birleştirilmelidir.

Diyabetes mellituslu yaşlı hastalarda, beslenme durumunu belirlemek için rutin olarak doğrulanmış bir araçla beslenme durumu taranmalıdır.
GPP - Güçlü fikir birliği

(\% 100 anlaşma)

GGP - Güçlü fikir birliği

(\% 100 anlaşma)

GPP - Güçlü fikir birliği (\% 96 anlaşma)

GPP - Güçlü fikir birliği (\% 100 anlaşma)

GPP - Güçlü fikir birliği (\% 100 anlaşma)

GPP - Güçlü fikir birliği (\% 100 anlaşma)

GPP - Güçlü fikir birliği (\% 100 anlaşma)

B - Güçlü fikir birliği (\%100 anlaşma)

A - Güçlü fikir birliği (\%100 anlaşma)

GPP - Güçlü fikir birliği

(\% 100 anlaşma)

0 - Oy birliği (\%83

anlaşma)

A - Güçlü fikir birliği (\%100 anlaşma)

A - Güçlü fikir birliği (\%100 anlaşma)

A - Güçlü fikir birliği (\%95 anlaşma)

GPP - Güçlü fikir birliği (\% 95 anlaşma)

GPP - Güçlü fikir birliği (\% 100 anlaşma)

0 - Güçlü fikir birliği (\%100 anlaşma)

B - Güçlü fikir birliği (\%100 anlaşma)

B - Güçlü fikir birliği (\%100 anlaşma)

GPP - Güçlü fikir birliği (\% 95 anlaşma)

GPP - Güçlü fikir birliği (\% 100 anlaşma)

GPP - Güçlü fikir birliği (\% 95 anlaşma)

A - Güçlü fikir birliği (\%100 anlaşma)

GPP - Güçlü fikir birliği (\% 95 anlaşma) 
59- Diyabetes mellituslu yaşlı hastalarda, yetersiz beslenme ve buna eşlik eden fonksiyonel zayıflamayı azaltmak için kısıtlayıcı diyetlerden kaçınılmalıdır.

60- Malnütrisyon ve malnütrisyon riski olan diabetes mellituslu yaşlı hastalarda beslenme durumu, yetersiz beslenen diyabetes mellitusu olmayan, yaşlı bireylerin önerilerine göre düzenlenecektir.

61- Yaşlı kadınlara her gün en az 1,6 L içecek, yaşlı erkeklere ise farklı yaklaşım gerektiren klinik bir durum olmadıkça her gün en az 2,0 L içecek verilmelidir.

62- $\quad$ Yaşlı bireylere, tercihlerine göre uygun doğrultuda içecekler verilecektir.

63- $\quad$ Tüm yaşlı bireyler, düşük alımlı sıvı kaybı riski altında dikkate alınmalı ve yeterli miktarda içecek tüketmeye teşvik edilmelidir.

64- Tüm yaşlı bireyler, sağlık bakım sistemi ile temasa geçtiğinde, yetersiz beslendiğinde veya yetersiz beslenme riski olduğunda eğer beklenmedik şekilde klinik durum periyodik olarak değişirse bu kişiler düşük alım sıvı kaybı yönünden taranmalıdır.

65- Yaşlı bireylerde düşük alımlı sıvı kaybını tanımlamak için doğrudan ölçülen serum veya plazma ozmolalitesi kullanılmalıdır.

66- Yaşlı bireyler düşük alımlı sıvı kaybını tanımlamak için doğrudan ölçülen serum ozmolalitesi $>300 \mathrm{mOsm} / \mathrm{kg}$ 'llk bir alt sinır kullanılmalıdır.

67- Doğrudan ölçülen osmolalite bulunmadığında, yaşlılarda düşük alımlı sıvı kaybını taraması için osmolarite denklemi $(>$ ozmolarite $=1.86 \times(\mathrm{Na}++\mathrm{K}+)+1.15 \times$ glukoz + üre + 14 (tümü mmol / L cinsinden ölçülür) $>295 \mathrm{mmol} / \mathrm{L}$ alt sınıra sahip olmalidır.

68- Cilt turgoru, ağız kuruluğu, kilo değişimi, idrar rengi veya özgül ağırlık gibi düşük alımlı sıvı kaybını değerlendirmek için yaygın olarak kullanılan basit işaretler ve testler, yaşlı bireylerde sıvı desteği durumunu değerlendirmek için kullanılmamalıdır.

69- Yaşlı bireylerde sıvı durumunu değerlendirmek için Biyoelektrik özdirenci yararı tespit edilmediği için kullanılması önerilmemektedir.

70- Yaşlı bireyler ve onların bakıcıları sıvı alımını değerlendirmek için uygun ölçümleri kullanabilir, ancak sağlık uzmanlarından periyodik olarak serum ozmolaritesinin değerlendirilmesini de istemelidir.

71- Ölçülen serum veya plazma ozmolalitesi $>300 \mathrm{mOsm} / \mathrm{kg}$ (veya hesaplanan osmolarite > $295 \mathrm{mmol}$ / L) olan daha yaşlı bireyler, yaşlı bireyler tarafindan tercih edilen içecekler biçiminde sıvı alımını arttırmaya teşvik edilmelidir.

72- $\quad$ Ölçülen serum veya plazma osmolalitesi $>300 \mathrm{mOsm} / \mathrm{kg}$ (veya hesaplanan osmolarite> $295 \mathrm{mmol} / \mathrm{L}$ ) olan yaşlı bireyler için, subkutan veya intravenöz sıvılar teşvik edici oral sıvı alımına paralel olarak sunulmalıdır.

73- $\quad$ Serum veya plazma ozmolalitesi $>300 \mathrm{mOsm} / \mathrm{kg}$ (veya hesaplanan osmolarite> 295 $\mathrm{mmol} / \mathrm{L}$ ) olan yaşlı bireyler için damar içi sıvılarda dikkate alınmalıdır.

74- Evde bakımda yaşayan yaşlılarda sıvı kaybını önlemek için kurumlar, tüm sakinlere kurumları arasında çok bileşenli stratejiler uygulamalıdır.

75- $\quad \mathrm{Bu}$ stratejiler arasında yüksek miktarda içecek bulunabilirliği, çeşitli içecek seçenekleri, sık sık içecek teklifi, yeterli sıvı alımı ihtiyacı konusunda personel farkındalığı ve yaşlı bireyler tuvalete götürmek için ihtiyaç duyduklarında personel desteği bulunmalıdır.

76- Yaşlıların kendileri, personel, yönetim ve politika yapıcılar dâhil olmak üzere yeterli sıvı alımını destekleme stratejileri geliştirmelidir.

77- $\quad$ Kurumlardaki yaşlı bireylere yönelik bakım planları, içecekler için kişisel tercihleri, nasıl ve ne zaman verileceklerinin yanı sıra kontinans desteğini de, içeceği teşvik etmek için kaydetmelidir. Bireysel engellerin ve içecek destekleyicilerin değerlendirilmesi, her bir yaşlı bireye özel içmeyi destekleme planlarına yol açmalıdır.

78- Düzenleyici düzeyde, kalıcı bireylerde ve hastalarda sıvı desteği risk kurumları tarafindan zorunlu izleme ve raporlama stratejisi göz önünde bulundurulmalıdır.

79- Disfaji belirtileri gösteren yaşlı bireyler, deneyimli bir konuşma ve dil terapisti tarafından değerlendirilmeli, tedavi edilmeli ve izlenmelidir. Beslenme ve sıvı desteği durumları, konuşma ve dil terapisti ve diyetisyen ile iş birliği içerisinde dikkatle izlenmelidir.

80- $\quad$ Yaşlı erişkinlerde aşırı kan kaybını takiben hacim kaybı, uzanmadan ayağa kalkmak ( $\geq 30 \mathrm{dk} / \mathrm{atım}$ ) postüral nabız değişimi veya durdurulamamasına neden olan ciddi postural baş dönmesi kullanılarak değerlendirilmelidir.

GPP - Güçlü fikir birliği (\% 100 anlaşma)

GPP - Güçlü fikir birliği

(\% 100 anlaşma)

B - Güçlü fikir birliği (\%96 anlaşma)

B - Güçlü fikir birliği (\%100 anlaşma)

GPP - Güçlü fikir birliği (\% 100 anlaşma)

GPP - Güçlü fikir birliği (\% 100 anlaşma)

GPP - Güçlü fikir birliği (\% 95 anlaşma)

B - Güçlü fikir birliği (\%94 anlaşma)

B - Güçlü fikir birliği (\%94 anlaşma)

A - Oy birliği $\left(\begin{array}{ll}\% & 83\end{array}\right.$ anlaşma)

A - Güçlü fikir birliği (\%100 anlaşma)

GPP - Güçlü fikir birliği (\% 94 anlaşma)

GPP - Güçlü fikir birliği (\% 100 anlaşma)

A - Güçlü fikir birliği (\%95 anlaşma)

A - Güçlü fikir birliği (\%95 anlaşma)

B - Güçlü fikir birliği (\%100 anlaşma)

B - Güçlü fikir birliği (\%100 anlaşma)

B - Güçlü fikir birliği (\%100 anlaşma)

GPP - Güçlü fikir birliği (\% 100 anlaşma)

GPP - Güçlü fikir birliği (\% 100 anlaşma)

GPP - Güçlü fikir birliği (\%94 anlaşma)

B - Güçlü fikir birliği (\%100 anlaşma) 
81- Yaşlı bireylerde, kusma veya ishal ile birlikte sıvı ve tuz kaybını takiben hacim azalması, bir dizi belirtilerin kontrol edilmesiyle değerlendirilmelidir. Aşağıdaki yedi işaretten en az dördüne sahip bir kişinin orta ile şiddetli hacim kaybı olabilir: Kafa karışıklığı, akıcı olmayan konuşma, ekstremite güçsüzlüğü, kuru mukoza zarları, kuru dil, sert dil, batık gözler

82- Hafif / orta / şiddetli sıvı kaybı olan yaşlı bireyler, oral, nazogastrik, subkutan veya intravenöz izotonik sıvılar almalıdır.
B - Güçlü fikir birliği (\%95 anlaşma)

B - Güçlü fikir birliği (\%95 anlaşma)

\section{SONUÇ ve ÖNERILER}

Hem dünyada hem ülkemizde gün geçtikçe artan yaşlı nüfusunda görülen fizyolojik değişiklikler ve hastalıklar yaşlı bireylerin beslenmesini ve sağlı durumunu etkilemektedir. Yaşlılarda beslenme durumunu korumak, geliştirmek, yeterli beslenmeyi ve sıvı durumunu desteklemek için bir yöntem yerine, birkaç yöntemin beraber kullanılması, ulusal düzeyde daha detaylı çalışmaların yapılması önerilmektedir. Yaşlı bireylerde beslenme girişimlerinin multidisipliner ekip olarak işbirliği ile tanılanması, beslenme ve sağlık durumlarının periyodik olarak değerlendirilmesi sıvı kaybı düzeylerini takip etmek için vücut ağırlığının izlenmesi malnütrisyon ve sıvı kaybı tedavisinde önem taşımaktadır.

$\mathrm{Bu}$ makale ile yaşamın her aşamasında bakım veren hemşireler için güncel rehber önerilerinin bilinmesi önerilerin klinik uygulamaya geçirilmesinde hız kazandıracaktır. Yaşlıların beslenme ve sıvı durumu ile yayınlanan bu rehberde öneriler doğrultusunda hasta bakımının gözden geçirilmesine ve klinik uygulamalara yararlı olacaktır.

\section{Finansal destek}

Finansal destek bulunmamaktadır.

\section{Çıkar çatışması}

Çıkar çatışması bulunmamaktadır.

\section{Yazarlık Katkıları:}

Tasarım/Design: M.Y.V.G., M.K.; Literatür tarama/Literature search: M.K.; Yazma/Writing: M.Y.V.G., M.K.

\section{KAYNAKÇA}

Arığul, S. (2013). Yaşlılarda Malnütrisyon Kılavuzu. Akademik Geriatri Derneği. http://www.akademikgeriatri.org/files/thn-kitap.pdf

Baz, S., Ardahan, M. (2016). Yaşlılarda Malnütrisyon ve Hemşirelik Yaklaşımları. Balıkesir Sağlık Bilimleri Dergisi, 5(3), 147-153.

Bratlund, C. V., O’Donoghue, C. R., Rocchiccioli JT. (2010). Dehydrationanddysphagia: Challenges in theolderadult. Journal of Medical Speech-Language Pathology, 18(3), 1-10.

Camina-Martín, M. A., De Mateo-Silleras, B., Malafarina, V., Lopez-Mongil, R., Niño-Martín, V., López-Trigo, J. A, et al. (2015). Nutritionalstatusassessment in geriatrics: Consensusdeclarationbythe Spanish society of geriatricsandgerontologynutritionworkgroup. Maturitas, 81(3), 414-419 https://doi.org/10.1016/j.maturitas.2015.04.018

Cemali, M., Cemali, Ö., Zafer, E. (2018). NutritionalStatus, Physical Performance and Fatigue in Geriatrics. Clinical Nutrition, 37, S180 https://doi.org/10.1016/j.clnu.2018.06.1653

Cindemir, C. (2008). Yeterli Ve Dengeli Beslenmenin Önemi. Medimagazin. https://www.medimagazin.com.tr/guncel/tryeterli-ve-dengeli-beslenmenin-onemi-11-666-16852.html

Güleç, E. (2013). Bakımevlerinde Kalan Yaşlı Bireylerin Sıvı Alım Durumları ve Etkileyen Faktörlerin İncelenmesi. Dokuz Eylül Üniversitesi. http://hdl.handle.net/20.500.12397/9888

Gürkan, A., Gülseven, B. (2013). Enteral Beslenme Bakımda Güncel Yaklaşımlar. Anadolu Hemşirelik ve Sağllk Bilimleri Dergisi, 16(2), 116 - 122. https://dergipark.org.tr/tr/download/article-file/29624

Hodgkinson, B., DipNsg, D. E., Wood, J. (2003). Maintaining oral hydration in olderadults: A systematicreview. International Journal of Nursing Practice, 9(3), 19-28. https://doi.org/10.1046/j.1440-172X.2003.00425.X

Hooper, L., Bunn, D., Jimoh, F. O. (2014). Fairweather-Tait SJ. Water-lossdehydrationandaging. Mechanisms of Ageingand Development, 136-137, 50-58. https://doi.org/10.1016/j.mad.2013.11.009 
Kıray, Vural, B., Zencir, G., İnci, F. (2018). Üç Farklı Yerleşim Alanında Yaşlıların Beslenme Durumunun İncelenmesi. İzmir Kâtip Çelebi Üniversitesi Sağlık Bilimleri Fakültesi Dergisi, 3(2), 1-7. https://dergipark.org.tr/tr/download/articlefile/513019

Mentes, J. (2006). Oral Hydration in OlderAdults: Greaterawareness is needed in preventing, recognizing, andtreatingdehydration. American Journal of Nursing, 106(6), 40-50. https://doi.org/10.1097/00000446-200606000$\underline{00023}$

Mistura, L., D’Addezio, L., Turrini, A. (2016). BeverageConsumptionHabits in ItalianPopulation: Associationwith Total WaterIntakeandEnergyIntake. Nutrients, 8(11), 674. https://doi.org/10.3390/nu8110674

Miller, HJ. (2015). Dehydration in theOlderAdult. Journal of Gerontological Nursing,41(9), 8-13. https://doi.org/10.3928/00989134-20150814-02

Mercanlıgil, Seyit M. (2008). Yaşlılıkta Beslenme Desteği. Beslenme ve Diyet Dergisi,35(2), 63-72.

Lochs H., Allison S. P., Meier R., Pirlich M., Kondrup J., Schneider S., Pichard C. (2006). Introductorytothe ESPEN Guidelines on EnteralNutrition: Terminology, Definitionsand General Topics. Clinical Nutrition,25(2), 180-186. https://doi.org/10.1016/j.clnu.2006.02.007

Özgüneş, G. (2013). Huzurevinde Yaşayan Yaşlılarda Beslenme Durumunun Taranması: Tarama Testleri Kıyaslaması. Hacettepe Üniversitesi Sağlık Bilimleri Üniversitesi.

Pekcan, G. (2008). Beslenme Durumunun Saptanması. T.C. Sağlık Bakanlı̆̆ı. Yayın No: 726 ISBN:978-975-590-242-5 Bask1: Klasmat Matbaacılık Ankara. https://sbu.saglik.gov.tr/Ekutuphane/kitaplar/A\%2014.pdf

Rubino M., Jin J., Gramlich L. (2020). NutritionalAssessment in Adults. İçinde Encyclopedia of Gastroenterology (2nd., pp. 709-716). https://doi.org/10.1016/B978-0-12-801238-3.66042-7

Saka, B., Kaya, O., Ozturk, G. B., Erten, N., \& Karan, M. A. (2010). Malnutrition in theelderlyanditsrelationshipwithothergeriatricsyndromes. $\quad$ ClinicalNutrition, $\quad 29 \quad(6), \quad 745-748$. https://doi.org/10.1016/j.clnu.2010.04.006

Saruhan, S., Pekcan, G. (2001). Yaşl1larda Antropometrik Yöntemlerle Beslenme Durumunun Değerlendirilmesi, Boy Uzunluğu ve Vücut Ağırlığının Saptanmasında Denklemler. Beslenme ve Diyet Dergisi.30(2), 32-41.

Sobotka L., Schneider SM., Berner YN., Cederholm T., Krznaric Z., Shenkin A. et al. (2009). ESPEN Guidelines on ParenteralNutrition: Geriatrics. ClinicalNutrition,28(4), 461-466. https://doi.org/10.1016/j.clnu.2009.04.004

Streicher, M., Themessl-Huber, M., Schindler, K., Sieber, C. C., Hiesmayr, M., \&Volkert, D. (2017). Whoreceives oral nutritionalsupplements in nursinghomes? Resultsfromthenutritiondayproject. ClinicalNutrition, 36(5), 1360-1371. https://doi.org/10.1016/j.clnu.2016.09.005

Tulukçu, G. (2019). Adana İli’nde İki Farklı Huzurevinde Yaşayan Yaşlılarda Malnutrisyon Durumunun Tarama Testleri ile Belirlenmesi [Yayınlanmamış Yüksek Lisans Tezi]. Hasan Kalyoncu Üniversitesi

TR Beslenme Raporu. (2015). Yaşlılık Döneminde Beslenme. Geriatri Derneği. Eğitim Serisi No.1 http://gidabilgi.com/Kategori/Detay/yaslilik-doneminde-beslenme-02c5bf www.beslenme.gov.tr

Volkert D., Beck, A.M., Cederholm T., Cruz-Jentoft A., Goisser S., Hooper L, et al. (2019). ESPEN Guideline on ClinicalNutritionandHydration in Geriatrics. ClinicalNutrition,38(1), 10-47. https://doi.org/10.1016/j.clnu.2018.05.024

Üstündağ, H. (2001). Total Parenteral Beslenme. Yoğun Bakım Hemşireleri Dergisi5(1), 41-43.

Yabancı, N., Akdevelioğlu, Y., Rakıcıŏlu, N. (2012). Yaşlı Bireylerin Sağlık ve Beslenme Durumlarının Değerlendirilmesi. Beslenme ve Diyet Dergisi,40(2), 128-135.

Yentür, E. (2011). Beslenme durumunun değerlendirilmesi. Klinik Gelişim Dergisi,24(1), 1-4.

Yeşildemir, Ö., Tek, N.A. (2018). Enteral Beslenme Desteği: Farklı Geriatrik Hastalıklarda Endikasyonlar, Uygulama Yolu ve Ürün Tercihi. Türkiye Klinikleri Journal Health Science,3(1), 71-9. 


\section{EXTENDED ABSTRACT}

Most of the diseases and health problems usually cause by unbalanced nutrition and malnutrition (Ardahan\& Baz, 2016). Malnutrition has been described as an imbalance between intake and a requirement that causes an alteration in a person's metabolism, compromises function and brings on a loss of body mass (Martin et al., 2015). Malnutrition is a nutritional condition in which a deficiency or excess (or imbalance) of energy, protein, and other nutrients causes measurable adverse effects on tissue/body form (body shape, size and composition) and function, and clinical outcome. (Lochs et al., 2006).

Nutritional status in elderly individuals is affected by many factors. (Vural et al., 2018). These factors change in the body during the ageing process, chronic diseases, drugs used, physical, psychological, social and economic condition (Aksoydan, 2008). Evaluation of nutritional status is important for identifying and managing people at high risk of disease and death (Rubino et al., 2020). Proper assessment of nutritional status is an integral part of early detection of malnutrition, identifying risks and causes of possible nutrient deficiencies, preparing action plans to improve patients' nutritional status, and evaluating effects on dietary interventions. (Martin et al., 2015).

\section{Evaluation of Nutritional Status in the Elderly}

There are many ways to assess nutritional status in older people:

- Malnutrition Risk Screenings

- Anthropometric Measurements

- Laboratory Findings

\section{Nutrition Methods}

Nutritional support treatment should be planned for patients whose malnutrition or malnutrition risk is determined as a result of screening and evaluations. In nutritional support treatment, if elderly individuals have oral intake, oral intake is supported in cooperation with a dietician and oral supplements are given(Ardahan\& Baz, 2016). If the enteral support were insufficient, enteral and parenteral mixture or parenteral nutrition routes can be used, respectively (Tek \&Yeşildemir, 2018). Enteral nutrition, starting from the mouth to the jejunum; It can be performed directly, with a tube, percutaneous intervention or surgical technique(Gülseven\&Gürkan, 2013). 'Total parenteral nutrition (hyperalimentation) is a method used to meet the needs of patients who are not able to take nutrients from the gastrointestinal tract"' (Üstündağ, 2001, p. 41). ESPEN (European Society of Parenteral and Enteral Nutrition) guidelines on enteral nutrition in geriatrics recommend the use of oral nutritional supplements in patients who are malnourished or at risk of malnutrition in order to increase energy and nutrient intake and to improve or maintain nutritional status (Streicher et al., 2017).Oral nutritional supplements were given tube feeding via nasogastric or percutaneous tubes (Lochs et al., 2006).

Many older individuals have cognitive deficits or other mental disorders that can increase the risk of temporary confusion during physical illnesses. In such cases, the nasogastric tubes may remove by the patient accidentally. In addition, age-related changes in the gastrointestinal tract should not be ignored, especially in critical illnesses and the efficiency of nutrient absorption. Therefore, oral / enteral and parenteral nutrition are not mutually exclusive and complement each other (Sobotka et al., 2009).

Since adequate and proper nutrition of the elderly are effective in increasing the living standards and prevention of diseases, the nutritional status of them should be evaluated regularly (Yabanc1 et al., 2012). There are guidelines developed on nutrition in the elderly:

1. "ESPEN Guide on Clinical Nutrition and Hydration in the Elderly" developed by the European Society of Clinical Nutrition and Metabolism (ESPEN) in 2019

2. "ASPEN and ESPEN Guidelines" developed in 2019 by the American Parenteral and Enteral Nutrition Association (ASPEN), the American Nutrition and Metabolism Definitions Association of the Academy of Nutrition and Dietetics

3. "Nice Guide on Nutrition Recommendations" developed by the British Geriatrics Society in 2009

4. "Clinical Practice Nutrition Guidelines on Nutrition in the Elderly" developed by the Hartford Geriatric Nursing Institute in 2008

\section{Fluid Loss in the Elderly}

There is no definitive definition for dehydration in the elderly. While dehydration is defined as faster weight loss of more than $3 \%$ of body weight, biochemically, dehydration is usually defined as serum sodium equal to or greater than 148 $\mathrm{mmol} / \mathrm{L}$ and / or blood urea nitrogen (BUN) ratio greater than 25. is defined as the situation in which it equals (Hodgkinson et al., 2003). Insufficient fluid intake in the elderly results in dehydration (Güleç, 2013). There are some symptoms that can help detect fluid loss. There may be symptoms such as decreased cell volume, confusion, headache, drowsiness, dizziness, dry wrinkled skin, and / or reduced skin turgor. Fluid loss can be defined by reduction in fluid excretion, dry lips, decreased salivary secretion, dry eyes, dry armpit or palm, low blood volume, slow capillary filling, low blood pressure, weak pulse, 
fast heartbeat or orthostatic hypotension. (Hooper et al.,2014).

\section{CONCLUSION AND RECOMMENDATIONS}

Physiological changes and diseases seen in the elderly population, which is increasing day by day both in the world and in our country, affect the nutrition and health status of the elderly. Instead of a method to maintain or improve the nutritional status of the elderly, to support adequate nutrition and fluid status, it is recommended to use several methods together, and to carry out more detailed studies at national level. Diagnosing nutritional interventions in elderly individuals as a multidisciplinary team, periodically evaluating their nutrition and health status, and monitoring body weight to monitor fluid loss levels are important in the treatment of malnutrition and fluid loss. With this article, knowing up-to-date guideline recommendations for nurses providing care at every stage of life will speed up the implementation of these recommendations into clinical practice. In line with the recommendations in this guide published with the nutritional and fluid status of the elderly, it will be useful to review patient care and clinical practices. 